\title{
ESPAÇOS VIRTUAIS MOVENTES DAS ESCOLAS OCUPADAS DE PORTO ALEGRE: O APOIO MÚTUO COMO BASE DA INTELIGÊNCIA COLETIVA
}

\author{
THE MOBILIZING VIRTUAL SPACES OF THE OCCUPIED SCHOOLS IN PORTO ALEGRE: \\ MUTUAL SUPPORT AS THE BASIS OF COLLECTIVE INTELLIGENCE
}

\section{ESPACIOS VIRTUALES QUE SE MUEVEN DE LAS ESCUELAS OCUPADAS DE PORTO ALEGRE: EL APOYO MUTUO COMO BASE DE LA INTELIGENCIA COLECTIVA}

\author{
Luciano Bedin da Costa ${ }^{1}$ \\ Manuella Mattos dos Santos ${ }^{2}$
}

\begin{abstract}
RESUMO
Este artigo analisa o movimento de ocupação escolar a partir dos espaços virtuais. No período de maio a junho de 2016 foram ocupadas 41 escolas estaduais na cidade de Porto Alegre. O movimento foi uma estratégia de resistência coletiva ao sucateamento e à desvalorização da educação pública por parte do Estado. Entre as escolas ocupadas, 40 delas utilizaram o Facebook como ferramenta de organização, de cooperação e de divulgação junto à sociedade. Para dimensionar o uso das redes neste movimento, foram coletadas informações das páginas virtuais de todas as escolas envolvidas, assim como o número e a qualidade das "curtidas" e dos compartilhamentos respectivamente. Os espaços virtuais possuem um caráter multiplicador e viral, propagando, de maneira rápida e direta, as informações aos seus usuários. Tem-se, portanto, uma poderosa rede de informações que constitui o que Pierre Lévy chama de inteligência coletiva, em que os sujeitos envolvidos reinventam as relações e as formas de aprendizagem. Nessas páginas os estudantes atuam de acordo com suas demandas, construindo relações horizontais com a comunidade virtual que, por meio de compartilhamentos e de interações, colaboram com a manutenção e a ampliação das ocupações. As trocas de conhecimento são mantidas pelo que Piotr Kropotkin designa como apoio mútuo: redes de colaboração espontânea que extrapolam fronteiras institucionalizadas. Uma vez que estabelecidas, estas relações alteram os territórios conhecidos, ultrapassando barreiras e limites geográficos. Para além de uma mera ferramenta de comunicação, esses espaços virtuais tornam-se dispositivos à constituição e ao fortalecimento de uma inteligência política coletiva; tão imprescindíveis, quanto os movimentos operados pelos estudantes no interior das escolas.
\end{abstract}

PALAVRAS-CHAVE: Exercício de cidadania. Aprendizagem mútua. Educação política.

\footnotetext{
${ }^{1}$ Docente da Universidade Federal do Rio Grande do Sul - UFRGS Docente da Faculdade de Educação e do Programa de Pós-Graduação em Psicologia Social e Institucional da UFRGS - Porto Alegre, RS.

Email: bedin.costa@gmail.com ORDIC: http://orcid.org/0000-0002-6350-2644

${ }^{2}$ Licencida em Ciências Biológicas - Universidade Federal do Rio Grande do SUL (UFRGS) - Porto Alegre, RS.

Email: manuella.mds@hotmail.com ORCID: http://orcid.org/0000-6638-3708

Submetido em: 30/11/2016 - Aceito em: 15/02/2017
}

(C) ETD-Educação Temática Digital Campinas, SP $\quad$ v.19 n.1 $\quad$ p. 49-72 jan./mar. 2017 


\title{
ABSTRACT
}

This article analyzes the movement of school occupations through virtual spaces. On the period from may to june 2016, 41 state schools were occupied by the community in the city of Porto Alegre. This movement was an act of collective defiance against the decay and depreciation of public education by the State. Forty of the occupied schools utilized Facebook as a tool of organization and cooperation with, and propagation to, society. To measure the importance of the use of social networking in these movements, data from the pages of all involved schools was collected, as well as the number and quantity of 'likes' and 'shares'. These virtual spaces have a disseminative and viral character, rapidly spreading information to their users by direct means. As such, here we find a powerful information network that Pierre Lévy would refer to as 'Collective Intelligence', where the involved subjects restructure their relations and their learning methods. In these pages, students act according to their own whims, building horizontal relations with the virtual community, that through 'shares' and interactions benefit the maintenance and growth of the occupations. The exchanges of knowledge are held together by what Piotr Kropotkin calls 'Mutual Support', networks of spontaneous cooperation that ignore barriers and geographical limits. Well beyond a simple tool of communication, these virtual spaces become devices for the organization and empowerment of a collective political intelligence, just as vital as the actions coordinated by students inside the schools.

KEYWORDS: Exercise of citizenship. Mutual learning. Political education.

\section{RESUMEN}

Este artículo analiza el movimiento de ocupación de escuelas desde los espacios virtuales. En el periodo de mayo a junio fueron ocupadas 41 escuelas de Porto Alegre como estrategia de resistencia colectiva al desguace y a la desvaloración de la educación pública por parte del Estado. Cuarenta de las escuelas ocupadas utilizaron el Facebook como herramienta de organización, cooperación y divulgación junto a la sociedad. Fueron colectados datos de las páginas virtuales de todas las escuelas involucradas, así como el número y calidad de los "me gusta" y compartimientos. Los espacios virtuales poseen un carácter multiplicador y viral que propaga de forma rápida y directa las informaciones a sus usuarios. Así se tiene una poderosa red de informaciones que constituyen lo que Pierre Lévy llama de inteligencia colectiva, donde los sujetos involucrados reinventan las relaciones y formas de aprendizaje. En estas páginas los estudiantes actúan de acuerdo con sus propias demandas construyendo relaciones horizontales con la comunidad virtual, que por medio de compartimientos e interacciones, colaboran con el mantenimiento y ampliación de las ocupaciones. Los intercambios de conocimientos son mantenidos por lo que Piotr Kropotkin designa como apoyo mutuo, redes de colaboración espontanea que sobrepasan fronteras institucionalizadas. Una vez establecidas, estas relaciones alteran los territorios conocidos, ultrapasando barreras y límites geográficos. Más allá de una simple herramienta de comunicación, los espacios virtuales se convierten en dispositivos para constitución y fortalecimiento de una inteligencia política colectiva tan imprescindibles cuanto los movimientos operados por los estudiantes en el interior de las escuelas.

PALABRAS CLAVE: El ejercicio de la ciudadanía. El aprendizaje mutuo. Educación política.

\section{A DUPLA OCUPAÇÃO DAS OCUPAÇÕES}

Em maio de 2016, estudantes secundaristas empossaram dezenas de escolas do estado do Rio Grande do Sul, sendo 41 delas na cidade de Porto Alegre. Em meio a projetos

\author{
(C) ETD-Educação Temática Digital Campinas, SP $\quad$ v.19 $\quad$ n.1 $\quad$ p. 49-72 jan./mar. 2017
}


de lei bastante polêmicos, como o $\mathrm{PL} 44 / 16^{3}$ e o $\mathrm{PL} 190 / 15^{4}$, e a pautas relativas à precarização do ensino público no estado, estudantes das escolas públicas decidem manifestar-se contra o crescente sucateamento da educação e dos espaços escolares. Durante 44 dias percebeu-se um crescimento viral das escolas ocupadas no estado, fenômeno que passou a invadir também os meios de comunicação e as mídias sociais. Em uma análise preliminar, diríamos que se tratou de uma 'dupla ocupação': ao mesmo tempo que as escolas eram apoderadas pelos estudantes, estas mesmas, passavam a tomar as atenções da sociedade. Se, por um lado, parte da grande mídia criminalizava o acontecimento, por outro, se percebia um forte movimento de mobilização por parte das mídias alternativas, verificado pela veiculação de matérias em sites, em blogs e pelo número de publicações/compartilhamentos através das redes sociais.

Este artigo pretende, pois, contribuir na compreensão desta problemática, analisando as ocupações das escolas estaduais de Porto Alegre operadas no espaço virtual, especificamente no Facebook. Dentre as 41 escolas estaduais ocupadas pelos secundaristas, somente uma não fez uso desta rede social. Tomados por esse fenômeno, foi realizado um mapeamento quali-quantitativo das publicações realizadas nesta plataforma, entre 11 de maio e 24 de junho de 2016, período em que se deu o início e o fim das ocupações. A análise dos dados foi feita a partir de autores que problematizam a temática dos espaços virtuais, tais como: Manuel Castells, que trata as redes sociais como um território capaz de ampliar relações e redimensionar as distâncias; Pierre Lévy, que discute as relações nos espaços virtuais e desenvolve a ideia de uma inteligência coletiva; Piotr Kropotkin, que evidencia a importância do apoio mútuo e das relações colaborativas na construção de outras formas de coletividade.

\footnotetext{
${ }^{3}$ Projeto de lei em tramitação pela Assembleia Legislativa do Rio Grande do Sul, muito questionado por alguns setores da sociedade civil, que veem nele uma ferramenta para precarização e privatização de fundações e empresas públicas ligadas ao ensino, à pesquisa e ao desenvolvimento social. Documento disponível em: http://proweb.procergs.com.br/temp/PL_44_2016 07022017152427 int.pdf?07/02/2017\%2015:24:28.

Acesso em: 06 fev. 2017.

${ }^{4}$ Projeto de Lei tramitado à época pela Assembleia Legislativa do Rio Grande do Sul, o qual instituiria, no âmbito do sistema estadual de ensino, o "Programa Escola Sem Partido". Documento disponível em: http://www.al.rs.gov.br/legislativo/ExibeProposicao/tabid/325/SiglaTipo/PL/NroProposicao/190/AnoProposic ao/2015/Origem/Px/Default.aspx Acesso em: 06 fev. 2017.
}

(C) ETD-Educação Temática Digital Campinas, SP v.19 $\quad$ n.1 $\quad$ p. $49-72 \quad$ jan./mar. 2017 


\section{OUTRA GEOGRAFIA À CONFLITUALIDADE POLÍTICA}

Pensar neste movimento de dupla ocupação nos faz refletir sobre outra forma de geografia política. A ocupação das escolas, por parte dos alunos, instaura um campo de possíveis à Educação, em que os protagonistas, ao invés de professores e sujeitos sindicalizados, são justamente a quem o próprio ensino se dirige: os alunos. Significantes como "greve" ou "paralização" tornam-se insuficientes diante do movimento operado pelos estudantes. Reforçado igualmente pela ocupação das mídias sociais - pela miríade de publicações que davam a ver o que as grandes mídias insistiam em ofuscar - percebe-se um potente desdobramento semântico ligado ao verbo ocupar, conduzindo-nos ao que Pelbart (2016) designa como 'outra geografia da conflitualidade':

E o que os secundaristas nos ensinaram é que também as formas de resistência se reinventam. A horizontalidade e a ausência de centro ou comando nas ocupações e nas manifestações dramatizaram uma outra geografia da conflitualidade. (PELBART, 2016, p.16-17).

Compreender a ocupação coletiva dos espaços exige, outrossim, uma compreensão mais aguçada acerca da própria noção de conflito. De uma maneira mais didática, diríamos que esta geografia da conflitualidade estaria ligada a três paisagens. Uma primeira, ligada ao regime de corpos, dos sujeitos que se encontram, em ato, nas escolas ocupadas. É necessário, pois, organização do coletivo e instauração de regras de convivência que tornem viáveis a ocupação ao longo dos dias - este será um dos tópicos analisado adiante. Uma segunda paisagem se dá na relação entre os ocupantes e o Estado, na negociação de suas pautas junto aos deputados e aos representantes da Secretaria Estadual de Educação. A terceira paisagem se dá através da própria ocupação das redes sociais, na forma como os estudantes se posicionam diante do seu próprio movimento e das represálias sofridas através dos meios virtuais. Esta última via nos faz pensar que, apesar de serem corpos marcados pela virtualidade, trata-se de interações reais, carregadas de afetos conflitivos das mais diferentes ordens e manifestações. A ocupação de um espaço virtual não isenta que os sujeitos se coloquem à parte ou blindados em relação ao mundo. O que parece estar em jogo é que, situados em outra geografia, os sujeitos acabam por vivenciar e dramatizar conflitualidades outrora inimagináveis - o que é publicado (comentário, opinião, nota de repúdio, etc.) ganha dimensões incalculáveis, repercutindo em uma comunidade que ultrapassa os domínios de camaradagem ou de amigos mais próximos. Qualquer palavra ou imagem é capaz de se engendrar em uma rede discursiva que ultrapassa as supostas

(C) ETD-Educação Temática Digital Campinas, SP $\quad$ v.19 $\quad$ n.1 $\quad$ p. 49-72 jan./mar. 2017 
intenções daquele que as veicula, adquirindo contornos políticos aguçados, capazes de mobilizar, ao mesmo tempo (e em tempo real) diferentes sujeitos e coletividades.

\section{ESPAÇOS VIRTUAIS MOVENTES}

Com Castells $(2003$; 2013) somos provocados a pensar nessa potência de deslocamento político gerada pelos espaços virtuais, à medida que instauram outras formas de conectividade e de agenciamentos coletivos. Não se trata apenas de pensar o que há de 'novo' nessas tecnologias virtuais (hardwares, softwares, aplicativos do momento), mas o que potencialmente estas ferramentas podem produzir em termos de novas tecnologias relacionais. $\mathrm{O}$ que está posto em jogo são as estratégias de interação e os desdobramentos operados, uma vez que acabam por fazer parte do cotidiano dos sujeitos que as usufruem ou não. Segundo Castells (2003, p.106), "o deslocamento da comunidade para a rede virtual é uma forma decisiva de organizar a interação" (CASTELLS, 2003, p. 106). As conectividades em redes virtuais atuam como meios de comunicação ativos, abrangendo uma grande diversidade de pessoas e de regiões geograficamente distantes. Uma vez formados, os coletivos que interagem a partir do ciberespaço passam a produzir ressonâncias nos espaços urbanos. Destarte, torna-se difícil uma distinção clara entre o que se passa nas redes virtuais e o que se opera no que o senso comum designa como 'mundo real'. Moventes, os espaços

virtuais acabam por borrar as fronteiras entre o real e o virtual, um operando enquanto duplo do outro, hibridizando-se à proporção que são colocados em movimento. Os espaços virtuais auxiliam, então, na dinâmica dos movimentos sociais, permitindo que os membros tenham acesso a informações independentemente do local em que estejam. O próprio sentido de comunicação se faz movente: ao invés de meros receptores, os sujeitos tornamse produtores e manipuladores sígnicos, selecionando e compartilhando conteúdos conforme seus interesses. É o caso que Sakamoto (2013, p. 95) nos aponta "quando alguém atua através de uma dessas redes, não está simplesmente reportando, mas também inventando, articulando, mudando. Isto, aos poucos, alterna também as formas de participação social".

Castells (2013) afirma que os movimentos no ciberespaço, ao mesmo tempo que são locais, também se conectam ao mundo pelo caráter de viralização das informações perpetuadas. Assim, as redes sociais se caracterizam como ferramentas de comunicação, de aceitação e de fortalecimento de movimentos sociais, fazendo com que uma pauta local atinja dimensões até então inimagináveis. Por meio de publicações nas redes sociais, toda

(C) ETD-Educação Temática Digital Campinas, SP $\quad$ v.19 $\quad$ n.1 $\quad$ p. 49-72 jan./mar. 2017 
comunidade virtual interage de modo instantâneo, ampliando, também, a geografia política destes sujeitos, logo na vida social das cidades. "Esse híbrido de cibernética e espaço urbano constitui um terceiro espaço, o espaço da autonomia, porque nele se pode garantir independência pela capacidade de se organizar no espaço livre das redes de comunicação" (CASTELLS, 2013, p. 160).

\section{DAS TECNOLOGIAS RELACIONAIS ÀS TECNOLOGIAS DA INTELIGÊNCIA}

Além das tecnologias relacionais, outro aspecto a ser verificado em relação aos espaços virtuais diz respeito ao que Lévy (1993) designa como tecnologias da inteligência. A comunidade construída no espaço virtual estabelece redes de laços sociais por meio de suas interações que, ricas em diversidades de expressões, possibilitam contato com novas experiências. Assim, renovam-se as formas de pensar. "A inteligência do todo não resulta mais de atos automáticos, pois é o pensamento das pessoas que inventa e põe em movimento o pensamento da sociedade" (LÉVY, 2000, p.31).

Lévy (2000) utiliza o termo inteligência coletiva para determinar os aprendizados que acontecem através da interação entre os sujeitos e da produção/compartilhamento de informações. Trata-se de uma inteligência que extrapola os domínios de um indivíduo, uma vez que é distribuída por toda parte e constantemente renovada pelos próprios coletivos que dela fazem uso. Perguntas como "quem criou isso?" ou "quem pensou aquilo?" tornamse complicadas ou mesmo inúteis. Operando em uma lógica rizomática, em que não há um

grande centro de comando, esta forma de inteligência acaba colocando em questão noções éticas como responsabilidade, direitos e deveres. "Em um coletivo inteligente, a própria comunidade assume como objetivo a negociação permanente da ordem estabelecida, de sua linguagem, do papel de cada um. Nada é fixo, pois os atos são coordenados e avaliados em tempo real" (LÉVY, 2000, p. 31).

Sendo assim, no que diz respeito à inteligência coletiva, faz-se necessário problematizar também a questão do comprometimento. Embora os coletivos virtuais estejam normalmente ligados a interesses comuns - seja pelo entretenimento ou por algum tipo de militância - isto não quer dizer que seus membros estejam unidos por uma mesma qualidade de comprometimento. $\mathrm{O}$ acesso e a interação com a comunidade, facilitados pelo uso de smartphones e de aparelhos portáteis, tornam os sujeitos conectáveis, ainda que seus vínculos estabeleçam nuanças bastante diferenciadas. Em uma comunidade virtual é possível estar ativamente presente em um determinado momento - interagindo e

(C) ETD-Educação Temática Digital Campinas, SP $\quad$ v.19 $\quad$ n.1 $\quad$ p. 49-72 jan./mar. 2017 
produzindo ressonâncias significativas junto ao coletivo - e no momento seguinte fazer-se ausente ou invisível. Trata-se do que Lévy (2000, p. 31) nos aponta, que "os indivíduos que animam este espaço do saber, longe de serem os membros intercambiáveis de castas imutáveis, são ao mesmo tempo específicos, múltiplos, nômades e em vias de transformações permanentes" (LÉVY, 2000, p. 31).

\section{POR UMA MUTUALIDADE EM TEMPOS DE RECOLHIMENTO}

Uma das noções que nos parece potente para pensar o movimento operado pelas ocupações secundaristas é a de apoio mútuo. Kropotkin (2009) compara sociedades ao longo da história da humanidade para elucidar que a sociabilidade é um fator extremamente importante para a sobrevivência de diferentes grupos. A colaboração - termo bastante recorrente nas relações de trabalho contemporâneas - é algo que se apresenta desde as primeiras sociedades, adquirindo maior ou menor intensidade conforme as configurações histórico-culturais de cada um dos tempos. No entanto, é preciso pensar o mutualismo para além de um espontaneísmo que acabaria por naturalizá-lo através de enunciados simplistas como: "é natural do homem a vida colaborativa". Com Kropotkin (2009) somos provocados a compreender o auxílio mutual como experiência construída pelos coletivos, muitas vezes a contrapelo da própria história a que estão inseridos. O desafio, segundo o autor, está em pensarmos a constituição de redes de apoio mútuo justamente quando o 'natural' de nosso tempo seria pensar/agir individualmente.

Se, por um lado, está cada vez mais complicado o fortalecimento de vínculos coletivos (em virtude das inúmeras demandas que se fazem urgentes no cotidiano das pessoas), por outro, nunca as pessoas estiveram tão presentes em comunidades para além de suas próprias famílias (Twitter, WhatsApp, Facebook, Instagram, Tinder, etc). Este aparente paradoxo - em estar e não estar ao mesmo tempo - performatiza na vida cotidiana uma espécie de jogo de presença e ausência, ao qual somos insistentemente convocados a participar. No entanto, algumas experiências mutualistas parecem eclodir no interior de comunidades supostamente mutuais das quais já fazemos parte, levando-nos a pensar na forma como nos engajamos ou nos relacionamos com os outros, na geografia de nossas próprias relações. Este parece ser o caso das ocupações das escolas e dos espaços virtuais por parte dos secundaristas, motivo agora de nossa análise

(c) ETD-Educação Temática Digital Campinas, SP v.19 $\quad$ n.1 $\quad$ p. 49-72 jan./mar. 2017 


\section{AS OCUPAÇÕES DAS ESCOLAS E DO FACEBOOK}

A cidade de Porto Alegre, capital do estado do Rio Grande do Sul, comporta uma população de 1.481.019 habitantes (IBGE, 2016), abrangendo uma rede de ensino com 258 escolas estaduais, 71 destas voltadas ao ensino médio. A rede municipal, por sua vez, é constituída por 96 escolas, sendo apenas 2 de ensino médio (INEP, 2015). De acordo com o Mapa das Regiões de Porto Alegre, há uma subdivisão da cidade em 17 macrozonas, conforme a proposta do Orçamento Participativo, organizado pela Prefeitura. Implementado em 1998, o Orçamento Participativo tem se caracterizado como "um processo dinâmico que se adequa periodicamente às necessidades locais, buscando sempre um formato facilitador, ampliador e aprimorador do debate entre o Governo Municipal e a população" 5 . O objetivo da divisão é que cada zona, contando com a participação dos cidadãos, possa pensar em soluções e em investimentos específicos de cada localidade, de acordo com suas prioridades (FEDOZZI, 1998). Dentro das temáticas propostas para discussão e para investimento estão a educação e a cultura, itens recorrentes nas pautas destas localidades.

O movimento das ocupações escolares em Porto Alegre, iniciado em 11 de maio de 2016, surge após a tomada das escolas estaduais de São Paulo, organizado pelos secundaristas no final de 2015. Em São Paulo, os estudantes reagiram contra o plano de reorganização do governo, que tinha por objetivo fechar 94 escolas, realocando estudantes (CAMPOS; MEDEIROS; RIBEIRO, 2016). Em Porto Alegre, as ocupações abrangeram ao todo 41 escolas públicas de ensino médio, representando $57 \%$ do contingente de escolas desta modalidade na cidade. Também, significativo foi o número de escolas que fizeram uso do Facebook como ferramenta virtual para fortalecimento do movimento - das 41 escolas manifestantes, apenas uma não fez uso desta rede social. Verifica-se, pois, o movimento de dupla ocupação supracitado que, paralelamente às apropriações das escolas, deu-se um potente movimento de invasão no território virtual por parte destas comunidades.

Esta pesquisa, de cunho exploratório, baseia-se na análise quali-quantitativa dos dados obtidos junto ao Facebook. A ideia de fazermos uso de dados quantitativos nos pareceu interessante para que pudéssemos dimensionar a força da mobilização no espaço virtual, informações que não revelam verdades absolutas por trás dos números, mas que

\footnotetext{
${ }^{5}$ Documento disponível em: http://www2.portoalegre.rs.gov.br/op/default.php?p secao=1 . Acesso em: 13 fev. 2017.
}

(C) ETD-Educação Temática Digital Campinas, SP $\quad$ v.19 n.1 $\quad$ p. 49-72 jan./mar. 2017 
delineiam paisagens possíveis de análise. Para isso, foram registrados e analisados os conteúdos das 40 páginas criadas no Facebook pelas escolas manifestantes, preservando-se dados pessoais e institucionais que possam comprometer os coletivos e os sujeitos envolvidos. Os dados foram coletados do dia 11 de maio até o dia 24 de junho de 2016, datas que marcaram, respectivamente, o início e o fim do movimento, sendo levado em consideração o número de "curtidas" (likes, termo original do Facebook) em cada página das ocupações, assim como a quantidade de compartilhamentos envolvidos. A partir desta primeira seleção foram criadas sete categorias de acordo com o caráter e intuito das publicações feitas pelos estudantes responsáveis pelas páginas das escolas ocupadas. Estas categorias ajudam a qualificar a análise, permitindo-nos avançar em relação aos números propriamente ditos. Deste modo, ficaram subdivididas as publicações em:

1) Comunicados: publicações informativas, que noticiam e esclarecem acontecimentos.

2) Organização: avisos de reuniões, mutirões de limpeza, alimentação, produção de cartazes.

3) Oficinas: convites à comunidade para participar das atividades, pedidos de pessoas dispostas a ministrar oficinas e divulgação fotográfica das oficinas que aconteceram.

4) Doações: alimentos, roupas, cobertores, materiais de artes - canetas, cartolinas, etc.

5) Apoio: compartilhamento de notas de instituições que apoiam as ocupações, além de notas dos estudantes apoiando outros movimentos sociais.

6) Relações entre as escolas: publicações que mostram conteúdos compartilhados entre as escolas, doação de alimentos e relatos de visitas entre as ocupações.

7) Outros: publicações não relacionadas com as categorias anteriores, que não possuem relação com o movimento de ocupação.

(C) ETD-Educação Temática Digital Campinas, SP v.19 $\quad$ n.1 $\quad$ p. $49-72$ jan./mar. 2017 


\section{ALGUNS DADOS PRELIMINARES}

Foi contabilizado um total de 2.457 publicações entre as 40 páginas das escolas ocupadas, tendo uma média de 62 postagens por escola ocupada. Já o número total de "curtidas" das publicações corresponde a 131.824, média de 54 "curtidas" por publicação, e um total de 21.194 compartilhamentos, com uma média de 9 compartilhamentos por publicação. Vale ressaltar que cada pessoa que acessa o conteúdo pode "curtir" e compartilhar somente uma vez cada publicação feita pela página. Os índices referentes a cada categoria encontram-se na tabela abaixo.

\section{TABELA 1}

Dados quantificados de publicações, de "curtidas" e de publicações nas páginas das escolas ocupadas em Porto Alegre.

\begin{tabular}{|lccc|}
\hline Categorias & № publicações & № "curtidas" & № compartilhamentos \\
\hline Oficinas & 803 & 33234 & 2714 \\
\hline Organização & 647 & 40169 & 6776 \\
\hline Comunicados & 517 & 42070 & 9541 \\
\hline Doações & 170 & 6742 & 1520 \\
\hline $\begin{array}{l}\text { Relações entre } \\
\text { escolas }\end{array}$ & 128 & 4606 & 233 \\
\hline Apoio & 105 & 4871 & 371 \\
\hline Outros & 8 & 132 & 39 \\
\hline
\end{tabular}

Fonte: Autores, pesquisa de campo.

As páginas das ocupações apresentam variedades no conteúdo publicado, uma diversidade que pode ser observada nos índices de publicações a cada diferente categoria (conforme Figura). É possível perceber que algumas publicações dominam nestes espaços, como a categoria 'oficinas' (34\%), 'organização'(27\%) e 'comunicados' (22\%), representando, juntas, $83 \%$ das publicações.

(C) ETD-Educação Temática Digital Campinas, SP v.19 $\quad$ n.1 $\quad$ p. 49-72 jan./mar. 2017 


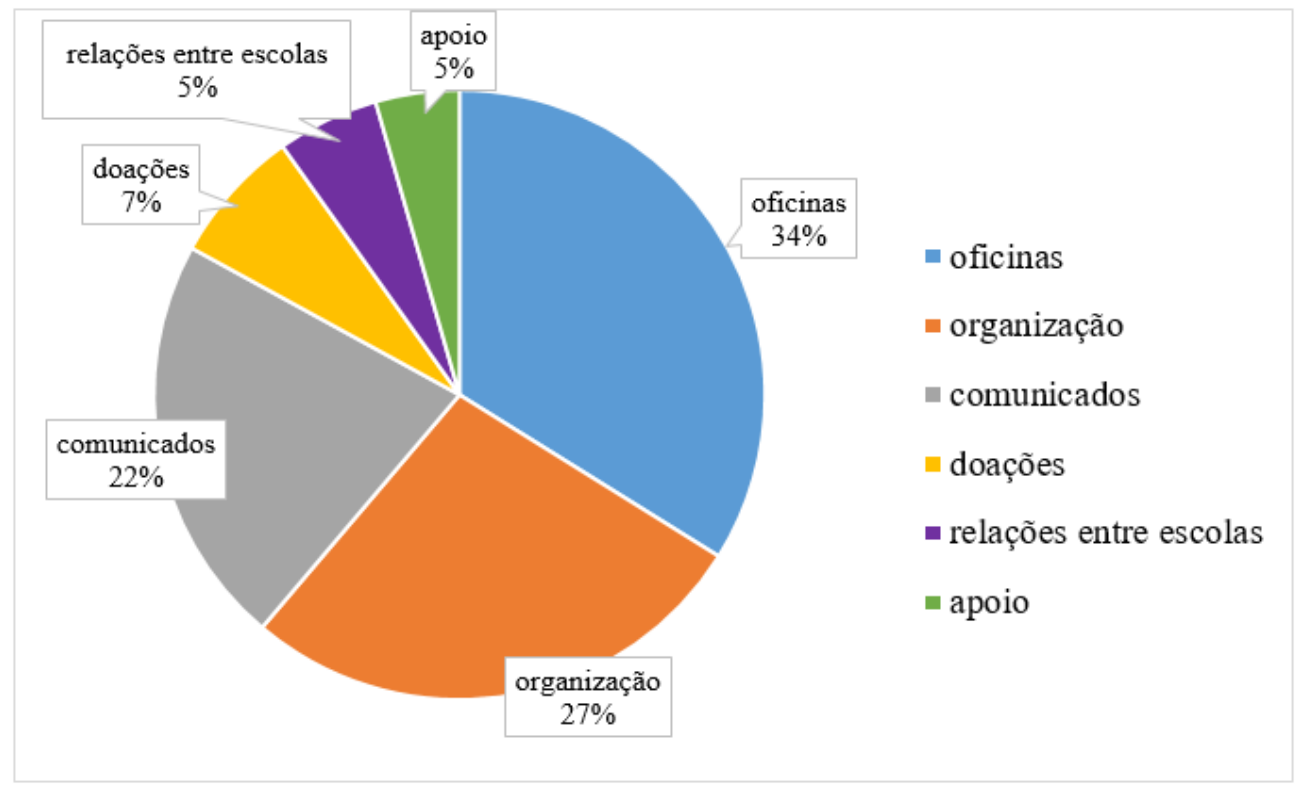

Gráfico 1 : Publicações por categoria apresentada nas páginas das escolas ocupadas em Porto Alegre. Fonte: Dados dos autores, pesquisa de campo.

O Facebook, como ferramenta de comunicação, apresenta um recurso para reagir aos conteúdos publicados: os likes, traduzido para o português como "curtidas". A partir desta ferramenta pode-se contabilizar a repercussão das informações divulgadas pelas escolas ocupadas na rede social, índices que demonstram o interesse da comunidade virtual no que está sendo produzido pelos estudantes das ocupações. Embora o maior número de publicações se refira a 'oficinas' (803), isto não se traduz em termos de número de "curtidas" e compartilhamentos. O item 'comunicados', com 517 publicações (3ำ na lista) é o maior responsável pelo número de "curtidas" e compartilhamentos, seguida das publicações sobre a 'organização'. Observa-se, aqui, uma inversão no que diz respeito à ordem dos três primeiros itens - quando levado em conta apenas o número publicações, tem-se a seguinte disposição: 10 'oficinas', 20 'organização' e 3o 'comunicados'; porém quando considerado o número de "curtidas”, altera-se a ordenação para: 10 'comunicados', 2ㅇ 'organização' e 3o 'oficinas'. Isto nos leva a pensar que a comunidade virtual reage de modo mais incisivo aos conteúdos que noticiam acontecimentos, gerando um número maior de compartilhamentos. Para termos uma melhor dimensão deste fenômeno, segundo a Tabela 1, o número de compartilhamentos referentes a 'comunicados' (9541) supera a soma das categorias 'oficinas' e 'organização' (9516). Apesar de haver mais publicações voltadas a 'oficinas' e a

(C) ETD-Educação Temática Digital Campinas, SP v.19 $\quad$ n.1 $\quad$ p. 49-72 jan./mar. 2017 
'organização', o mutualismo parece estar mais aquecido na rede virtual quando o que está em jogo é a notificação de acontecimentos e de posicionamentos dos coletivos diante de fatos mais emblemáticos (como o informe de situações de violência ou negligência por parte do estado e da sociedade em geral). Esta realidade se aproxima daquilo que Hardt \& Negri (2014) chamam de produção de verdade, a qual não se impõe verticalmente através das grandes mídias, mas se produz à medida que os próprios coletivos veiculam suas informações e opiniões através da rede. "Sim, precisamos descobrir a verdade, mas, também e sobretudo, precisamos produzir novas verdades, que podem ser criadas somente por meio de singularidades em redes se comunicando e estando juntas" (p.56).

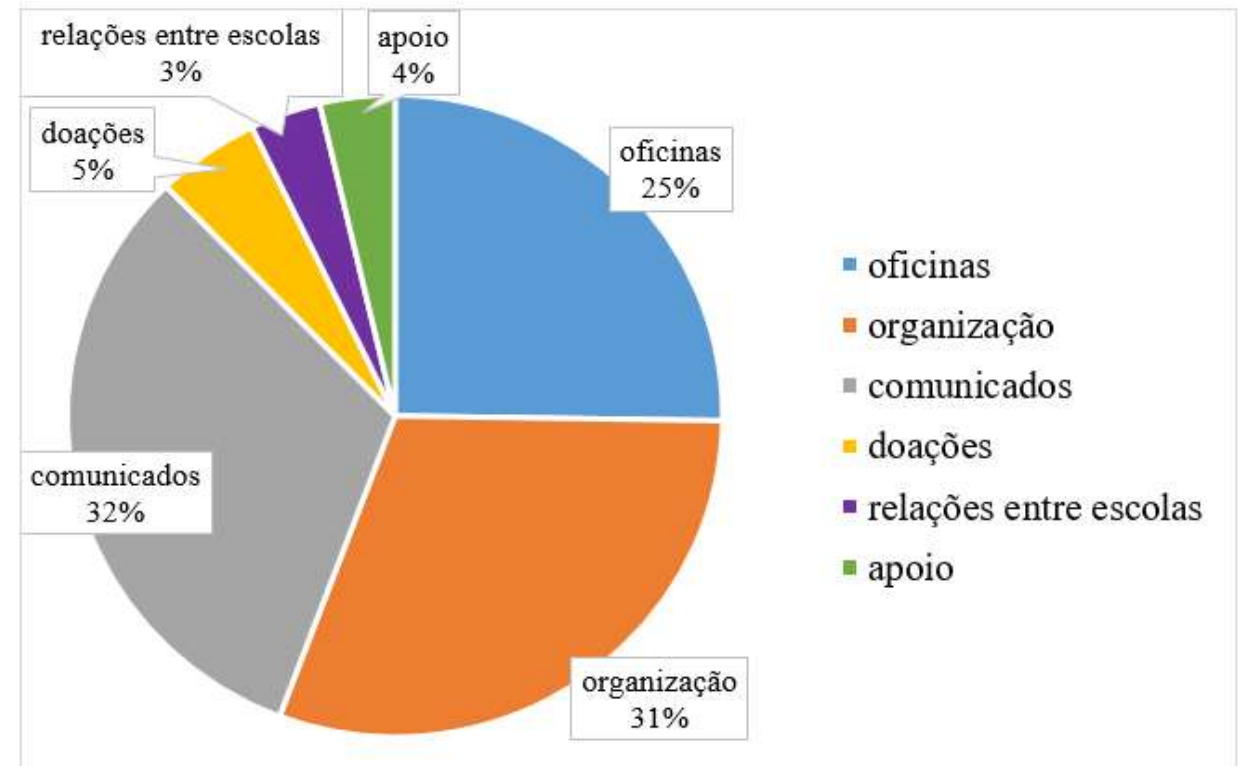

Gráfico 2 : “Curtidas” por categoria de publicação nas páginas das escolas ocupadas em Porto Alegre. Fonte: Dados dos autores, pesquisa de campo. 


\section{ESCOLA OCUPADA NÃO É ESCOLA PARALISADA}

Realizamos inúmeras atividades de formação, de debate, de reflexão coletiva e diversas oficinas ${ }^{6}$.

Depois de um mês ocupando nossa escola, tivemos diversas aulas e oficinas, novos aprendizados ${ }^{7}$.

Visto ter sido o item com maior número de publicações (34\%), faz-se necessário discutir alguns pontos acerca da presença das oficinas nas ocupações. De modo a romper com o discurso de que 'escola ocupada é escola paralisada', e pensando na formação dos seus próprios alunos, os coletivos das ocupações se organizaram de maneira a movimentar outras aprendizagens. Ao invés das aulas tradicionais - motivos de muitas queixas por parte desses alunos - optou-se por novos formatos, dentre estes: as oficinas. De acordo com Betancourt (1991), as oficinas possuem uma conotação de elaboração, de construção e de aprendizado coletivo, o que acaba por aproximá-las de experimentações mais democráticas como as vividas nas ocupações. As oficinas, por lidarem com agentes e temáticas diversas, tendem por dinamizar a concepção tradicional de aprendizagem, em que um sujeito - o professor - acaba por se tornar o responsável pela transmissão de saberes, estes previamente determinados pelos currículos e parâmetros educacionais. A rede de apoio mútuo operada pelas ocupações gerou uma demanda até então reprimida, de pessoas interessadas em contribuir na formação dos alunos ocupantes das escolas, disponibilizando seus saberes aos coletivos interessados. Nas publicações que divulgam as oficinas, aparecem temáticas de música, teatro, yoga, dança, hortas, conversas, debates sobre gênero e questões raciais. Nesta categoria aparecem muitas publicações de fotos e de vídeos, uma forma de divulgar e ao mesmo tempo retribuir virtualmente a atenção dedicada pelos voluntários.

\section{9 “BADERNEIRO É QUEM PARCELA SALÁRIO DO PROFESSOR”}

"Por trás dos textos publicados estão as multiplicidades. No ciberespaço, o saber não deve ser visto como algo abstrato, mas algo visível, que exprime uma população" (LÉVY,

\footnotetext{
${ }^{6}$ Publicado em 19 de junho de 2016. Disponível em: https://www.facebook.com/ocuparb/posts/1069640026434817 em 07/02/2017. Acesso em: 07 fev. 2017.

7 Publicado em 15 de junho de 2016. Disponível em: https://www.facebook.com/ocupaetesed/posts/500912353439531:0. Acesso em: 07 fev. 2017.
}

(C) ETD-Educação Temática Digital Campinas, SP $\quad$ v.19 $\quad$ n.1 $\quad$ p. 49-72 jan./mar. 2017 
1999, p.162). A categoria 'comunicados' engloba as publicações com o intuito de informar e sensibilizar os usuários da comunidade virtual. Aparecem, aqui, esclarecimentos sobre os motivos das ocupações, avisos sobre últimas decisões feitas em assembleias, avisos de reuniões abertas a toda a comunidade e reivindicações do movimento. O interessante é que, paralelamente às macro-demandas relacionadas às políticas de educação, verifica-se a manifestação de toda uma pauta local, ligada à realidade de cada escola propriamente dita. É o caso da publicação do Colégio Estadual Florinda Tubino Sampaio, em 24 de maio de 2016, em que se pode verificar a presença de queixas bastante específicas, tais como:

- Falta de merenda (NÃO tem para todos os alunos);

- Precariedade da estrutura física (parede de uma sala desabando, problemas na fiação elétrica, goteiras, janelas quebradas, falta de água diversas vezes);

- Projetos não realizados (falta de um arquiteto para o projeto do refeitório e elevador de acessibilidade);

- Falta de funcionários (porteiro, limpeza);

- Redução do material didático (menos livros, tinta para canetas);

- Classes e cadeiras precárias (falta de manutenção);

- Fogão prestes a explodir;

- Esgotos entupidos. ${ }^{8}$

Em 22 das páginas, as publicações com maior visibilidade dentro desta categoria são as que informam os motivos da ocupação para a comunidade virtual. Trata-se de publicações preocupadas, não somente em informar a sociedade acerca da ocupação das respectivas escolas, mas também em oferecer uma informação politicamente mais precisa. É o caso do anúncio de ocupação da Escola Estadual de Ensino Técnico Irmão Pedro, em 18 de maio de 2016, em que se presencia a necessidade do coletivo em desmistificar estereótipos a eles atribuídos:

\begin{abstract}
É importante lembrar aos pais, à direção da escola, aos policiais, e à sociedade em geral, que não estamos cometendo crime algum. Afinal, lutar não é crime! Nós não somos baderneiros. Baderneiro é quem parcela salário do professor, baderneiro é quem corta a merenda das escolas, baderneiro é que está destruindo com o Rio Grande e com o Brasil. Nós estamos querendo salvar o Irmão Pedro para contribuir na grande luta pela educação que o Brasil e seu povo precisam: a educação popular. $^{9}$
\end{abstract}

\footnotetext{
${ }^{8}$ Disponível em: https://www.facebook.com/ocupatubino/posts/240238643019947. Acesso em: 07 fev. 2017.

${ }^{9}$ Publicação em 18 de maio de 2016. Disponível em:

https: //www.facebook.com/permalink. php?story fbid=270165806669436\&id=269948590024491 . Acesso em: 07 fev. 2017.
}

(C) ETD-Educação Temática Digital Campinas, SP $\quad$ v.19 $\quad$ n.1 $\quad$ p. 49-72 jan./mar. 2017 
Nas redes virtuais, as pessoas podem compartilhar esses comunicados e fazer com que mais pessoas visualizem os recados dados pelos estudantes. Os espaços virtuais formam redes de conexões, que conectam não só pessoas, mas também realidades, ideias e significados. Estas páginas possuem um caráter multiplicador, pois aumentam a repercussão dos fatos ocorridos no momento em que qualquer pessoa compartilha as informações publicadas.

$\mathrm{Na}$ categoria 'comunicados' estão incluídas as notas que esclarecem ataques feitos por pessoas contrárias às ocupações. Algumas das publicações relatam e esclarecem desentendimentos com a polícia militar, assim como dificuldades nos acordos com a direção da escola, que, em muitos casos, se opõe ao movimento. Além de outros atritos que ocorrem dentro da ocupação, inclusive entre os participantes, são também esclarecidos nestas redes virtuais:

Desde os primeiros dias da ocupação do Paula Soares, nós ocupantes, viemos sofrendo com constantes ameaças, agressões verbais e até físicas de um grupo de pais do Desocupa, que visa terceirizar as reintegrações de posse através dos pais que não aceitam a luta dos alunos. (...) Só nesta semana já tentaram nos trancar dentro da escola, colocando, durante a madrugada, um cadeado deles no nosso portão, hoje colaram o cadeado que nos protege e protege a escola com cola bonder, nos mantendo ocupados por alguns minutos tentando nos livrar do cárcere privado (...). Fomos agredidos, filmados mesmo quando pedimos direito de imagem, considerando que atualmente a ocupação é composta apenas por menores de idade, somos constantemente ameaçados, caluniados, expostos em rede social e ofendidos com as palavras de mais baixo calão. (...) Não aceitaremos mais essa violência, estamos agindo de forma judicial, mas não usaremos as mesmas "armas" que os agressores, apelam a agressões as quais nos submetem, não devolveremos na mesma moeda. Seguiremos resistindo, na luta para que nós, os filhos desses agressores e as próximas gerações tenham direitos, sejam tratados com dignidade, respeito e não tenham que passar pelo o que estamos passando para que nossos direitos sejam cumpridos (...) Sabemos que se o prédio da nossa escola passasse por uma fiscalização, certamente seria interditado, todos que nele estão correm risco de vida, a juventude que está ocupando veio para mudar, ocupamos pela educação e é por ela que continuaremos na luta. ${ }^{10}$

${ }^{10}$ Disponível em: https://www.facebook.com/OCUPAPS/posts/1611040829209289:0 . Acesso em: 07 fev. 2017.

(C) ETD-Educação Temática Digital Campinas, SP $\quad$ v.19 $\quad$ n.1 $\quad$ p. 49-72 jan./mar. 2017 


\title{
10 “EM 30 DIAS APRENDI COISAS QUE EM 18 ANOS EU NÃO TINHA APRENDIDO”
}

\begin{abstract}
No lugar de uma representação em escalas lineares e paralelas, em pirâmides estruturadas em 'níveis', organizada pela noção de saberes 'superiores', a partir de agora devemos preferir a imagem de espaços de conhecimentos abertos, contínuos, em fluxo, e não lineares (LÉVY, 1999, p.157).
\end{abstract}

O segundo maior número de publicações (conforme Tabela 1) mostra as atividades relativas a 'organização' dos coletivos. Trata-se de postagens que relatam a criação de comissões nas escolas (mídia/divulgação), pedidos de doações (alimentos, materiais), organização de atividades (contato com oficineiros e pessoas interessadas em contribuir). Nesse item encontram-se as publicações com registros fotográficos dos estudantes, os mutirões de limpeza que realizam, a elaboração de cartazes explicativos para pendurar na escola e outros momentos de vivências destes coletivos dentro das ocupações. Algumas páginas publicam fotos que mostram como estão sendo feitas as divisões de dormitórios, assim como a divulgação das refeições. Nas páginas aparecem registros dos estudantes e, por vezes, colaboradores cozinhando coletivamente.

Há um grande número de reações a estas publicações, sendo a segunda categoria com maior número de "curtidas" e compartilhamentos (conforme Figuras 1 e 2). A maioria das fotos publicadas nas redes são registros da organização do movimento, pois realçam o envolvimento dos estudantes na ocupação. O número significativo de visualizações e os compartilhamentos destas publicações demonstram a sensibilidade despertada na comunidade virtual, quando percebem que os estudantes, também, passam a ocupar outros lugares que não somente o de vândalos, de rebeldes e de baderneiros.

Na página da escola E.E.E.M Padre Rambo, alguns dos estudantes criaram um espaço para divulgação de relatos das experiências dos estudantes durante a ocupação. Estes relatos estão nas publicações finais da página, marcando o momento de reflexão acerca das experiências de cada aluno. Pelos relatos é possível observar a narrativa de aprendizados pessoais e, também, a importância da unificação criada entre os estudantes. É o caso da publicação abaixo, em 20 de junho de 2016:

(C) ETD-Educação Temática Digital Campinas, SP $\quad$ v.19 $\quad$ n.1 $\quad$ p. 49-72 jan./mar. 2017 
Certamente somos mais conscientes e racionais agora, aprendemos que quando não pensamos com a nossa própria cabeça alguém pensara por nos! Em 30 dias eu aprendi coisas que em 18 anos eu não tinha aprendido. Fiz muitos amigos e tenho certeza que vou levar muitas amizades de lá para a vida. A jornada às vezes pode valer mais que a recompensa final! ${ }^{11}$

\section{UMA CARTOGRAFIA POSSÍVEL DAS ESCOLAS OCUPADAS}

A análise das ocupações através do Facebook permite-nos traçar outra cartografia acerca da rede constituída, visualizar alguns movimentos de mutualismo virtual entre as escolas envolvidas. A sexta categoria de nossa pesquisa, 'relações entre as escolas', é a que procura visualizar e contabilizar as publicações que se preocuparam em divulgar conteúdos de outras escolas, representando $5 \%$ do número total publicações (conforme Figura 1) e 3\% do número total de "curtidas" (conforme Figura 2). Nas páginas relativas a esta categoria encontramos o compartilhamento de publicações de outras ocupações, pedidos de apoio e divulgação de ações de escolas parceiras. Também aparecem nesta categoria as publicações relativas a visitas realizadas entre os estudantes de diferentes escolas ocupadas. Em 110 das 128 publicações desta categoria (conforme Tabela 1) estão voltadas ao movimento de ocupação das escolas de Porto Alegre; em 8 aparecem publicações de ocupações de outras cidades do Rio Grande do Sul; 4 referentes a escolas do Ceará e 6 foram os relatos de visitas a escolas não ocupadas em Porto Alegre.

O mapa apresentado abaixo (Figura 4) demarca a área da cidade de Porto Alegre, com os pontos de localização das escolas manifestantes. As áreas coloridas no mapa representam 17 macrorregiões propostas pelo Orçamento Participativo da cidade. No mapa é possível observar que as 40 escolas ocupadas se distribuem em 14 destas regiões, ocupando de modo mais intenso a região central da cidade.

\footnotetext{
11 Publicação disponível em: https://www.facebook.com/permalink.php?story fbid=1750679391855062\&id=1736737649915903. Acesso em: 07 fev. 2017.
}

(C) ETD-Educação Temática Digital Campinas, SP $\quad$ v.19 n.1 $\quad$ p.49-72 jan./mar. 2017 


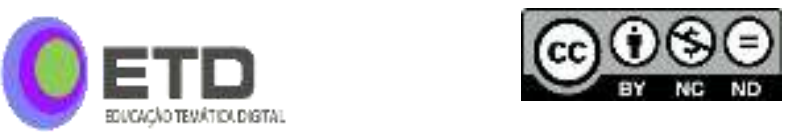

DOSSIÊ

DOI 10.20396/etd.v19i1.8647802

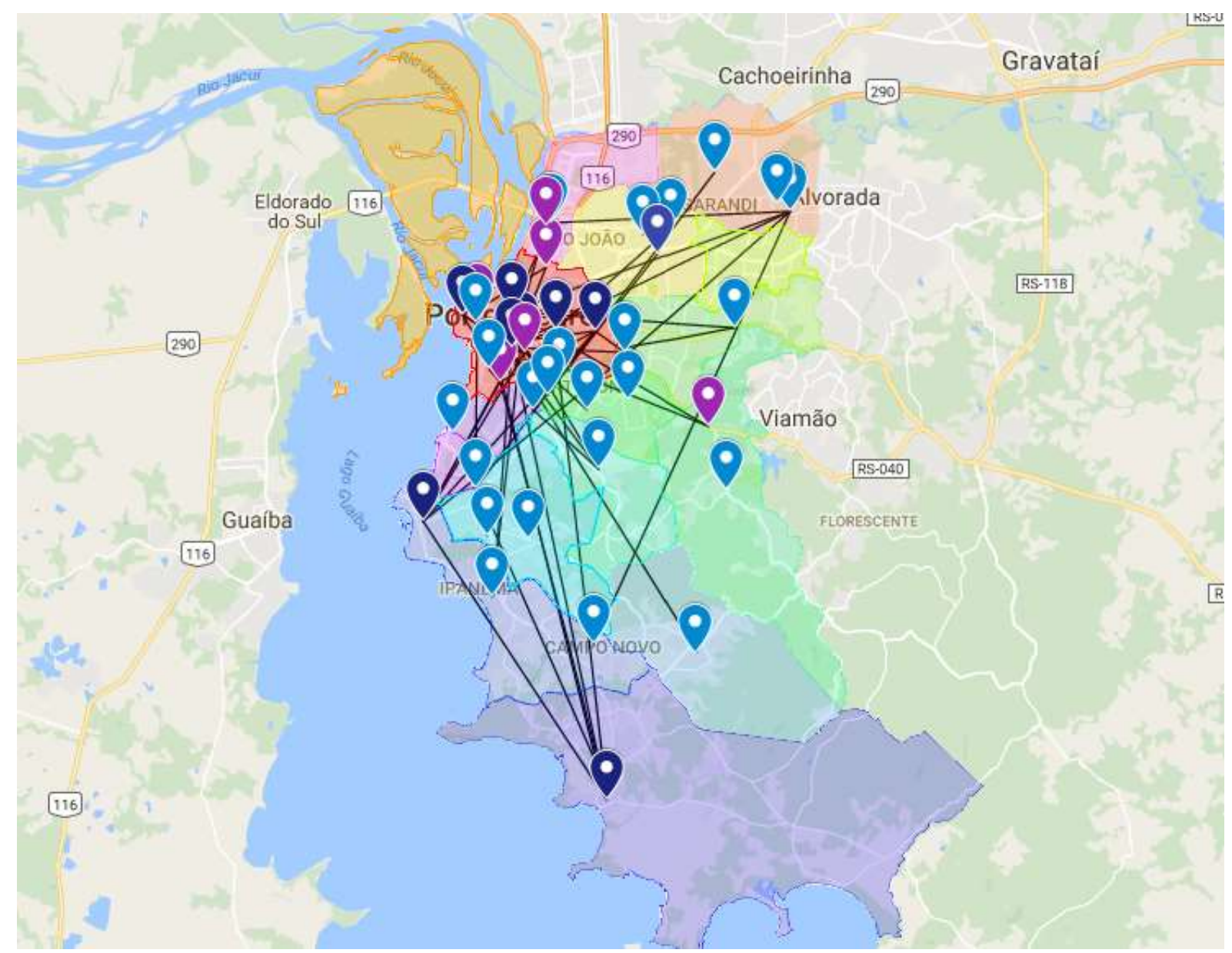

FIGURA 1: Mapa das escolas ocupadas nas macrozonas de Porto Alegre.

Fonte: GoogleMaps. Dados da autora, pesquisa de campo ${ }^{12}$

As diferentes cores dos pontos de demarcação das ocupações são relativas aos números de "curtidas" das páginas virtuais de cada escola. Os pontos em azul escuro (10) representam as escolas com maior número de "curtidas" (3788 - 1296), os pontos em roxo (6) as escolas que tiveram entre 1249 - 887 "curtidas" e os pontos em azul claro (24) são as escolas que menos de 806 pessoas "curtiram" suas páginas. Conforme supracitado, as escolas ocupadas se distribuem de modo concentrado no território da cidade. Por mais que haja uma distribuição nas diferentes regiões, percebe-se que as escolas com maior visibilidade nesses espaços virtuais são escolas da região central. Uma hipótese para esse fenômeno pode estar relacionada ao fato da concentração urbana ser maior nestas áreas,

${ }^{12}$ Imagem disponível em: https://www.google.com/maps/d/viewer?mid=1uUYORJOumakqRLsznCHLy3tGmo\&\|l=-30.1002685131288\%2C-51.27772317285155\&z=8 . Acesso em: 07 fev. 2017

(C) ETD-Educação Temática Digital Campinas, SP v.19 $\quad$ n.1 $\quad$ p. $49-72 \quad$ jan./mar. 2017 
com um maior número de alunos nestas escolas, além de serem geograficamente mais acessíveis. De toda forma, há de se considerar a presença de escolas geograficamente mais distantes que, no entanto, conseguem manter-se ativamente presentes na interatividade virtual.

As linhas entre as ocupações correspondem a todas as publicações que relacionam uma escola à outra. Nos compartilhamentos entre as páginas de ocupação há pedidos de alimentos, esclarecimentos sobre fatos ocorridos em algumas ocupações, doações de alimentos de uma escola para outra, reuniões e visitas entre ocupações, manifestações na rua com estudantes de diferentes escolas e divulgação de novas escolas que aderem ao movimento ao longo do processo.

A despeito de tamanha confluência de linhas, capaz de tornar o mapa acima visualmente curioso, percebemos a quase inexistência de relatos de interações presenciais entre as escolas. Em apenas 6 das 128 publicações são relatados visitas entre as escolas, levando-nos a pensar que, apesar de todos os facilitadores, o Facebook e demais redes sociais não garantem, por si só, que estas interações se deem de modo efetivo no cotidiano presencial dos sujeitos. Neste ponto, concordamos com Hardt \& Negri (2014, p. 32), que o procedimento on-line de "adicionar como amigo" não substitui a potência de amizade que se dá em um regime de corpos.

\section{AS DESOCUPAÇÕES}

O movimento de desocupação é iniciado quando um grupo com cerca de 70 estudantes ocupa o saguão da Assembleia Legislativa do Estado do Rio Grande do Sul, solicitando uma reunião com o superintendente geral da Assembleia. Inicia-se, portanto, uma sequência de negociações, resultando em um acordo coletivo em 14 de junho de 2016. Incomodados, os coletivos de algumas ocupações imediatamente se manifestam por meio das páginas virtuais, contrários ao acordo feito. A partir disso, surgem publicações que declaram haver divergências dentro do próprio movimento, pois o acordo não teria sido suficientemente discutido entre as escolas envolvidas.

(C) ETD-Educação Temática Digital Campinas, SP v.19 n.1 $\quad$ p. 49-72 jan./mar. 2017 
No dia 14/06, o grupo de estudantes que ocupou a ALERGS, em sua maior parte composto por representantes de entidades, fechou um acordo com o governo o qual não respeitava reais reivindicações dos estudantes, prometendo desocupar todas as escolas, sem dialogar com elas. Desde então, o movimento das ocupações se enfraqueceu drasticamente tornando cada vez mais difícil uma vitória real ${ }^{13}$.

Além da escola acima, 12 outras escolas anunciaram em suas páginas serem contra o acordo e não apoiar as entidades estudantis envolvidas. Na tentativa de lidar com estas diferenças foi criado o Comitê das Escolas Independentes - CEI, grupo autônomo composto por estudantes secundaristas, o qual buscou uma renegociação com o governo que considerasse algumas pautas importantes, como: a não criminalização das manifestações estudantis e a garantia que os protagonistas das ocupações não fossem de forma alguma punidos.

O processo total de desocupação se deu em 24 de junho de 2016, após algumas escolas já terem sido desocupadas na negociação anterior. Faz-se necessário destacar que 33 escolas com páginas no Facebook publicaram comunicados acerca do fim da ocupação, sendo que 24 delas têm a publicação de aviso de desocupação com o maior número de "curtidas" entre as categorias. Nestas páginas, 23 escolas ocupadas enfatizam a importância da integração do grupo durante o movimento e agradecem o apoio de todos que ajudaram de alguma maneira. Os estudantes falam dos aprendizados que tiveram convivendo juntos e da importância de fortalecer as relações. Em algumas destas páginas, o aviso de ocupação relembra sobre a necessidade de seguir lutando, suscitando a continuidade do movimento, mas por outras vias.

Ocupar sua escola é apenas uma entre diversas estratégias de luta. É por isso que o CEI decidiu se manter como uma Frente Combativa pela Educação. A luta com certeza não acaba aqui! As escolas públicas serão ouvidas de forma diferente após esses 41 dias. ${ }^{14}$

A publicação final do Instituto de Educação General Flores da Cunha (reproduzida abaixo na íntegra), em 22 de junho de 2016, ajuda-nos a compreender melhor o sentimento de otimismo por parte dos estudantes:

\footnotetext{
13 Publicado em 22 de junho de 2016, Disponível em: https://www.facebook.com/permalink.php?story fbid=193541581047364\&id=1876884349660120 . Acesso em: 07 fev. 2017.

${ }^{14}$ Publicado em 22 de junho de 2016, disponível em: https://www.facebook.com/permalink.php?story fbid=193541581047364\&id=1876884349660120 . Acesso em: 07 fev. 2017.
}

(C) ETD- Educação Temática Digital Campinas, SP v.19 n.1 $\quad$ p.49-72 jan./mar. 2017 
Valeu a pena cada um dos 36 dias. Valeu a pena cada noite fria que dormimos no colégio. Cada mutirão de limpeza. Cada assembleia. Cada oficina. Cada discussão que tivemos. Cada ato.

Nós da Ocupa IE gostaríamos de agradecer a todos os que nos apoiaram durante esses 36 dias, a todos os pais, professores e ex-alunos que estiveram do nosso lado, a todos que deram a cara a tapa e lutaram com a gente, a todas as doações, de alimento, de materiais de limpeza, de apoio jurídico ou até mesmo de tempo para "apenas" nos ouvir. Gostaríamos de agradecer a cada um que se propôs a realizar uma oficina na nossa ocupa e dizer que vocês foram muito importantes durante todo esse processo! Aprendemos muito nesses 36 dias, não foram apenas aulas de cidadania, matemática, química, história, teatro, música, e tantas outras oficiais que seria difícil listar todas aqui. Mas acima de tudo, aprendemos a ser cidadãos, que lutam pelos seus direitos e não tem medo do que possa acontecer. Conhecemos pessoas e fizemos amizades que certamente durarão mais do que o simples ano letivo. 36 dias que não foram fáceis, mas não nos arrependemos de nada e sabemos que nossa luta é muito maior, porque além de lutarmos para nós, lutamos também para que as futuras gerações tenham uma educação digna e de qualidade, para que a escola prepare para a VIDA e não apenas para o vestibular. ${ }^{15}$

\section{PORQUE QUEREMOS MUITO MAIS DO MUNDO}

"Mexer-se não é mais deslocar-se de um ponto a outro da superfície terrestre, mas atravessar universos de problemas, mundos vividos, paisagens dos sentidos", lembra-nos Lévy (2000, p.14). A quebra de fronteiras do pensamento e os deslocamentos possíveis a partir das redes sociais são ferramentas de empoderamento dos jovens como sujeitos dos próprios processos de formação, essa realidade é evidenciada nas ocupações escolares. Ao invés de meros receptores, estes jovens tornam-se produtores e difusores de saberes e de informações, caracterizando uma nova paisagem político-cognitiva. Falamos de toda uma inteligência coletiva potencializada pelo uso das ferramentas virtuais, sem as quais seria praticamente impossível visualizar tamanho alcance social.

Os movimentos de ocupação das escolas e das redes virtuais são experiências que permitem a reinvenção das relações no espaço escolar e na própria forma como concebemos o conceito de democracia. "Esses movimentos são poderosos pelas suas relações horizontais, como multidão, e sua insistência na democracia em todos os níveis é

\footnotetext{
${ }^{15}$ Publicação disponível em: https://www.facebook.com/OcupalE/posts/991477970966640 . Acesso em: 07 fev. 2017.
}
(C) ETD- Educação Temática Digital
Campinas, SP v.19 n.1
p. 49-72 jan./mar. 2017 
mais do que uma virtude, mas uma chave para o seu poder" (HARDT; NEGRI, 2014, p.142). Durante os 44 dias que marcaram o início e o fim das ocupações fomos - como usuários das redes sociais - igualmente ocupados: tomados por um sentimento de que nem tudo está perdido e pela necessidade de revermos urgentemente nossos conceitos acerca da juventude e da escola. Apesar das ambivalências e paradoxos, olhar para o que fora construído ao longo do movimento é algo que pode nos ensinar, e muito, acerca do que somos e para onde buscamos ir.

\begin{abstract}
Mas além de lutarmos, estávamos aprendendo uns com os outros a sermos fortes, compreensivos, fiéis, dedicados e carinhosos. Este período que passamos unidos foi mais do que simplesmente uma experiência de convivência. Mas sim, uma aula de cidadania diária ${ }^{16}$.
\end{abstract}

Se as ocupações acarretarão ou não em conquistas concretas no que diz respeito essas escolas públicas não saberemos. De toda forma, estes movimentos nos brindaram com algo que agora nos parece indubitável: que "querer mais do mundo" pode ser um ato, e não apenas um discurso idealista. Ou, como tão bem nos apresentam esses secundaristas: ${ }^{i}$

\footnotetext{
Nós, estudantes e professores da Escola Técnica Estadual Irmão Pedro, nos unimos para denunciar e lutar por mudanças. Afinal de contas o lema do Irmão Pedro diz ser uma escola "para quem quer mais do mundo". E nós queremos muito mais do mundo! ${ }^{17}$
}

\footnotetext{
16 Publicação em 24 de maio de 2016, disponível em: https://www.facebook.com/ocupatubino/posts/240238643019947 . Acesso em: 07 fev. 2017.

${ }^{17}$ Publicação em 18 de maio de 2016, disponível em: https://www.facebook.com/permalink.php?storyfbid=270165806669436\&id=269948590024491 . Acesso em: 07 fev. 2017.
}

(C) ETD-Educação Temática Digital Campinas, SP $\quad$ v.19 n.1 $\quad$ p.49-72 jan./mar. 2017 


\section{REFERÊNCIAS}

BETANCOURT, Arnobio M. El taller educativo. Santafé de Bogotá: Secretaría del Convenio Andrés Bello, 1991.

BRASIL, Ministério da Educação, Instituto Nacional de Estudos e Pesquisas Educacionais INEP. Censo educacional, 2015. Disponível em: http://cod.ibge.gov.br/17QNE. Acesso em: 10 nov. 2016.

BRASIL. Instituto Brasileiro de Geografia e Estatística (IBGE). Diretoria de Pesquisas, Coordenação de População e Indicadores Sociais. População estimada em 2016. Porto Alegre: IBGE, 2016.

CAMPOS, Antonia M. ; MEDEIROS, Jonas; RIBEIRO, Márcio M. Escolas de luta. São Paulo: Veneta, 2016. 352 p. Coleção Baderna

CASTELLS, Manuel. Redes de indignação e esperança: movimentos sociais na era da internet. Rio de Janeiro: Jorge Zahar, 2013. 271 p.

CASTELLS, Manuel. A galáxia da internet: reflexões sobre a internet. Rio de Janeiro: Jorge Zahar, 2013. 325 p.

FEDOZZI, Luciano. Esfera pública e cidadania: a experiência do Orçamento Participativo de Porto Alegre. Ensaios FEE, Porto Alegre, v. 19, no 2, 1998. 236 - 271 p.

FIGUEIREDO, Nébia Maria. Método e metodologia na pesquisa científica. 2a ed. São Caetano do Sul, São Paulo: Yendis, 2007. 256 p.

HARDT, Michael; NEGRI, Antonio. Isto não é um manifesto. São Paulo: n-1 edições, 2014. $144 \mathrm{p}$.

KROPOTKIN, Piotr, 1842, 1921. Apoio mútuo: um fator de evolução. São Sebastião: A Senhora Editora , 2009. 271 p.

LÉVY, Pierre. A inteligência coletiva: por uma antropologia do ciberespaço. 3. ed. São Paulo: Loyola, 2000. 212 p.

LÉVY, Pierre. As tecnologias da inteligência: o futuro do pensamento na era da informática. São Paulo: Ed. 34, 1993.

(C) ETD-Educação Temática Digital Campinas, SP v.19 $\quad$ n.1 $\quad$ p. $49-72 \quad$ jan./mar. 2017 
LÉVY, Pierre. Cibercultura. São Paulo: Ed. 34, 1999. 264 p.

LÉVY, Pierre; AUTHIER, Michel. As árvores do conhecimento. São Paulo: Ed. Escuta, 1995. $188 \mathrm{p}$.

MUSSOI, Eunice Maria; FLORES, Maria Lúcia; BEHAR, Patrícia Alejandra. Comunidades virtuais: um novo espaço de aprendizagem. Novas Tecnologias de Educação. CINTED UFRGS. Porto Alegre, v. 5, no 1, julho 2007.

PALLOFF, Rena M.; PRATT, Keith. Construindo comunidades de aprendizagem no ciberespaço: estratégias eficientes para salas de aula on-line. Porto Alegre: Artmed, 2002. $248 \mathrm{p}$.

PELBART, Peter. Carta aberta aos secundaristas. São Paulo: n-1 edições, 2016. 23p. Secretaria Municipal de Planejamento Estratégico e Orçamento. Mapa das regiões do Orçamento Participativo de Porto Alegre, 2016. Disponível em:

http://observapoa.com.br/default.php?p secao=46. Acesso em: 30 out. 2016.

SAKAMOTO, L. et al. Cidades rebeldes: passe Livre e as manifestações que tomaram as ruas do Brasil. São Paulo: Boitempo: Carta Maior, 2013. 95 - 100 p.

\footnotetext{
' Revisão gramatical do texto por:

Tanisa Burchert Miranda. Email: tanisabmiranda@yahoo.com.br
} 